\title{
FINANCIAL ACCOUNTING APPROACH FOR DECISION MAKING: A CASE ON FOOD RETAILER COMPANY
}

\author{
Yuniarti Hidayah Suyoso Putra \\ Fakultas Ekonomi UIN Maulana Malik Ibrahim Malang \\ Telp: 081334119895/Email: yuniarti_hidayah@yahoo.com
}

\begin{abstract}
This paper aims to evaluate food retailer company based on the financial accounting approach by analyzing statement of financial performance, statement of financial position, statement of cash flow, common size and key market indicators. The research focuses on Woolworths' Company Limited over period of five years from 1999 to 2003 and compare with competitors Coles Myer Limited and Foodland Limited. The results show Woolworths' performance over the five years period is improving with gradual increase in net profit margin, return on assets, and the decrease in tax rate and interest expense. Whilst, In short term, working capital ratio and quick assets ratio has been decreased over the past five years which means its current assets is not able to cover up its current liabilities. However, in examining debtor's turnover (in days), inventory turnover and operating cycle the company is able to sell out its inventories and collect debts quickly which may increase the company's ability to raise funds when it is needed. Furthermore, in the long term financial stability, Woolworths is using a high level of debt which contributes two thirds of the company's total assets. Meanwhile, shareholders' funds only increased as half as it liabilities from 1999 to 2003. Therefore, based on all the analysis, Woolworths is predicted to remain in the food and drug retailing industry.
\end{abstract}

\section{Key Words: Financial Accounting, Performance, Decision Making}

\section{INTRODUCTION}

Financial accounting can be thought of broadly as the part of accounting system that tries to meet the needs of various external users groups. This is does by means of an annual report which includes statements of financial performance, financial position and cash flow, information required by law and additional information which the entity wishes to supply (Bazley, Hancock, Berry and Jarvis, 2004). This information is crucial for decision making. Therefore, the disclosure of financial information in the competitive 
environment is essential in order to avoid asymmetries information on the market. In a line, it is obviously that most of accounting standards encourage companies to disclose all materials information, although for some information is not a mandatory required.

Meanwhile, food retailer industry is a growing business over the decade head to head with the growth of mankind population. This situation attracts the investor to invest in type of company. Woolworths, for example, was founded in January 1958 by acquiring BCC Stores Holding Co Ltd, providing the company with an entrance into food retailing. In January 1985, the company acquired the Australian Safeway Store Group, making it the largest food retailer in Australia (Aspect Dat Analysis, 2004).

The company is operating under food and drug retailing sector, which its main activity is supermarket operations. Besides supermarket, the company is also operating in the sale of petrol (Caltex Woolworths and Woolworths Plus Petrol), liquor (Dan Murphy, Woolworths/Safeway liquor, BWS Beer Wine and Spirits, Baily\&Baily, and First Estate fine wine shops), general merchandise stores (Big W), and consumer electronics (Dick Smith Electronics, PowerHouse, and Tandy). The company also operates Ezy Banking, which offers banking products with backing from Commonwealth Bank Australia.

According to annual report (Connect4, 20014), Woolworths' has 20 major shareholders who hold $44.22 \%$ of its total shares. J P Morgan Nominees Australia Limited is the largest holders $(12.7 \%)$ followed by Westpac Custodian Nominees Limited (9\%) and National Nominees Limited (8.19\%). The risk of the company as measured by beta $(0.50)$ is higher than the industry $(0.33)$. It means that Woolworths is classified as a risky company.

Therefore, the approach to financial accounting on this food retailer company will provide an excellent overview for top management and investor's decision making related to performance and future prediction.

\section{METHODOLOGY}

Financial accounting approach for Woolworths' (WOW) is analyzed based on ratio analysis, statement of cash flows analysis, common-size analysis and future prediction performance. Time periods of analysis are from 1999 to 2003. For the 
industrial comparison, Coles Myer Limited (CML) and Foodland Limited (FOA) that operate in similar industry (food and drug retailing) are taken. All data for Woolworths and competitors are based on company's website, Annual Report Database and Aspect Huntley Database.

Ratio analysis is used to evaluate operating performance and financial stability. Return on stockholders' equity and return on assets are used to assess Woolworths' operating performance, while financial stability employs short-term liquidity and longterm liquidity ratios. Short-term liquidity includes working capital ratio, quick assets ratio and operating cycle ratio. Meanwhile, long-term liquidity consists of proprietary ratio based on assets, proprietary ratio based on liabilities, gearing ratio and interest coverage ratio.

Further, examining Woolworths' statement of cash flows will help to predict company's ability in maintaining and increasing cash from current operations (White, Sondhi, and Fried, 2003). Key market indicators are also explained as a part of this analysis. Meanwhile, common size analysis (include the balance sheets and profit and loss statement) is used as another technique to evaluate Woolworths' performance. In addition, future prediction can be drawn based on all of those analyses.

However, there are several assumptions to cover up some limitations in calculation for Woolworth and its competitors:

1. Shareholders' funds calculate from total shareholders' equity, which include Woolworths' income notes (WINs) and outside equity. Since WINs are perpetual and has no maturity date, it is treated as equity (Woolworths annual report, 2003).

2. For debtor turnover rate, total sales are taken as credit sales.

\section{RESULTS AND DISCUSSIONS}

\section{Company's Strategies}

Essentially, the key strategies of Woolworths include consistent financial performance and very tight capital management policies. Based on Annual Reports Collection (2004) the consistent financial performance of the Group is achieved through simultaneous strong growth in sales turnover combined with further reductions in the cost of doing business. These strategies are combined with very tight capital management policies of 
inventory reduction and share buy-backs to drive robust growth in earnings per share (EPS). In 2003, as the company's profits increase, Woolworths has bought back its shares of \$534 million in order to increase the shareholders' value.

Regarding supermarket operations, Woolworths had implemented Project Refresh Level I initiatives over last 4 years, which concerned about business restructuring program and cost savings program. The Project Refresh Level I initiative showed favorable results which had delivered cost savings to $2.4 \%$ of sales which are $\$ 1.7$ billion over 4 years. Now, the company has been struggling for Project Refresh Level II, which is end-to-end supply chain improvement program (Woolworths annual report, 2003).

Moreover, Woolworths' current funding depends heavily on external borrowing and Woolworths' income notes (WINS) that has no maturity date. Company's external borrowing includes bank loans, bank overdrafts, commercial papers and medium term notes (Woolworths annual report, 2003).

\section{Financial performance}

\section{Return on stockholders' equity}

Woolworths return on stockholders' equity has increased substantially over the past 5 years. As compared to its competitors such as CML (12.13\%) and FOA $(13.18 \%)$, Woolworths' return on stockholders' equity is much higher $(33.44 \%)$ in 2003 . This increase is due to:

- The gradual increase in net profit margin from $1.47 \%$ in 1999 to $2.32 \%$ in 2003

- $\quad$ The increase in return on assets from $12.28 \%$ in 1999 to $16.29 \%$ in 2003

- Fell in effective interest rate from 2.42 in 2002 to $2.03 \%$ in 2003

- The gradual decrease in taxation rate from $36.71 \%$ in 1999 to $29.48 \%$ in 2003 . 
Graph 1: Return on Shareholders' Equity

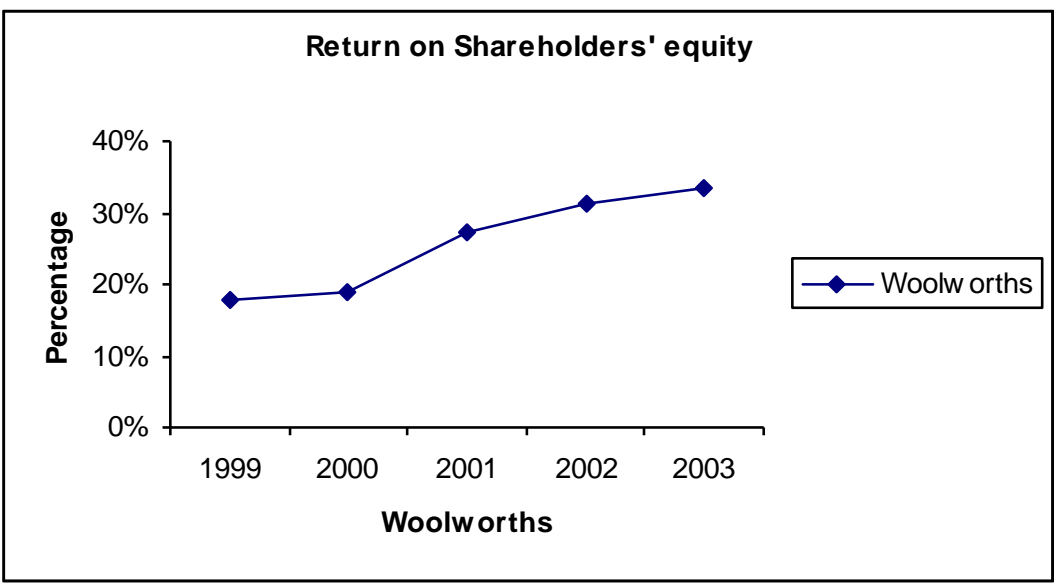

\section{Return on Assets}

The increase in return on assets can be explained by an increase in asset turnover ratio from 3.99 times in 1999 to 4.53 times in 2003 and a slight increase in earnings before interest and tax margin over the past 5 years. Woolworths' return on assets $(16.29 \%)$ was higher than its competitors (8.42\% and $10.28 \%$ for CML and FOA respectively).

\section{Ways of improving profitability}

It is recommended that the company should improve its profitability in several ways:

- Increase sales and reduce more cost of doing business

- Make sure that Woolworths' inventory is being purchased at the lowest price by evaluating the price offered by other suppliers.

- Reduce costs of borrowing by investigating alternative creditors

\section{Financial stability of the company}

It is essential that the firm must be able to pay its debts when they fall due in both short term and long term.

\section{Short term liquidity}

\section{Working capital ratio}

This ratio indicates whether the firm has enough short term assets to cover its short term debts. Woolworth's working capital ratio is deteriorating from 1.1 in 1999 to 0.81 in 2003 
which shows that Woolworths' current assets are not able to cover its current liabilities. There is a big jump in current liabilities due to:

- The accounts payable have increased nearly double from \$1281.1 millions in 1999 to $\$ 2078.9$ millions in 2003.

- Accrual liabilities have also increased significantly in 2003 (\$541.9 millions) comparing with 1999 (\$318.7 millions).

- A large increase in current interest bearing liabilities. Woolworths had managed their current interest bearing liabilities from \$341.7 millions in 2001 to \$34.1 millions in 2002 but these liabilities have gone up again to \$150.5 millions in 2003.

So, Woolworths now has less capacity to meet its financial commitments over the next 12 months using their current assets. Hence, the company may run into trouble if their creditors want money back quickly.

\section{Graph 2: Working Capital Ratio}

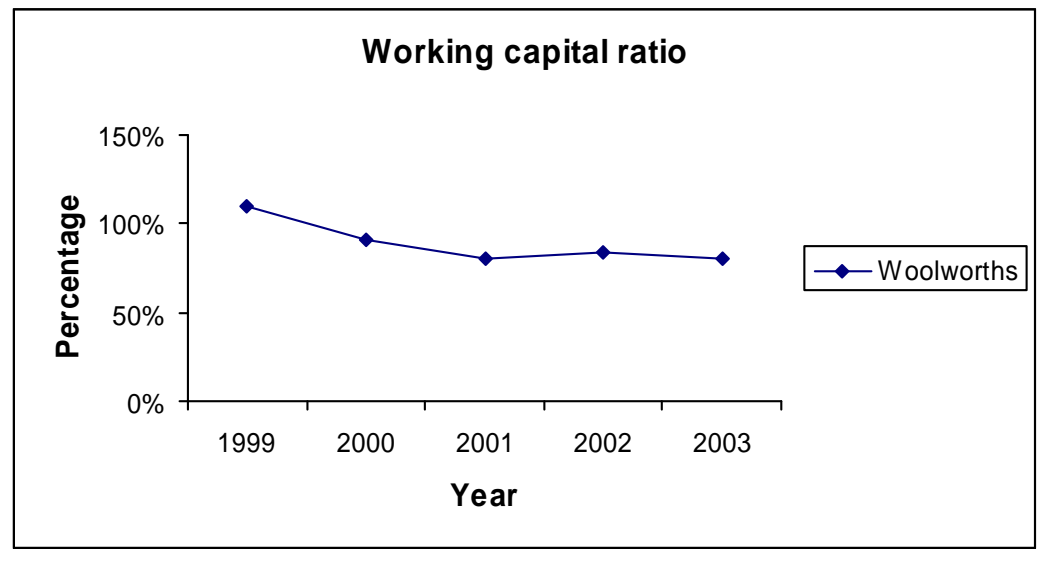

\section{Quick asset ratio}

By excluding inventory asset from the formula, this ratio focuses on whether company's liquid asset can meet its current liabilities which may become payable almost immediately without disrupting normal trading. Woolworths's quick asset ratio has fallen from $28 \%$ in 1999 to $24 \%$ in 2003 . This is due to a significant increase in current liabilities (from \$ 2029.2 million in 1999 to \$ 3243.6 million in 2003) while only a slight increase in the quick assets. This ratio is quite low in comparing with Woolworths' 
competitors: CML had ratio of $42 \%$ in 2003 as well as the other competitor (FOA) whose ratio is above $50 \%$.

\section{Graph 3: Comparison of Woolworths and its competitors' Quick Asset Ratio}

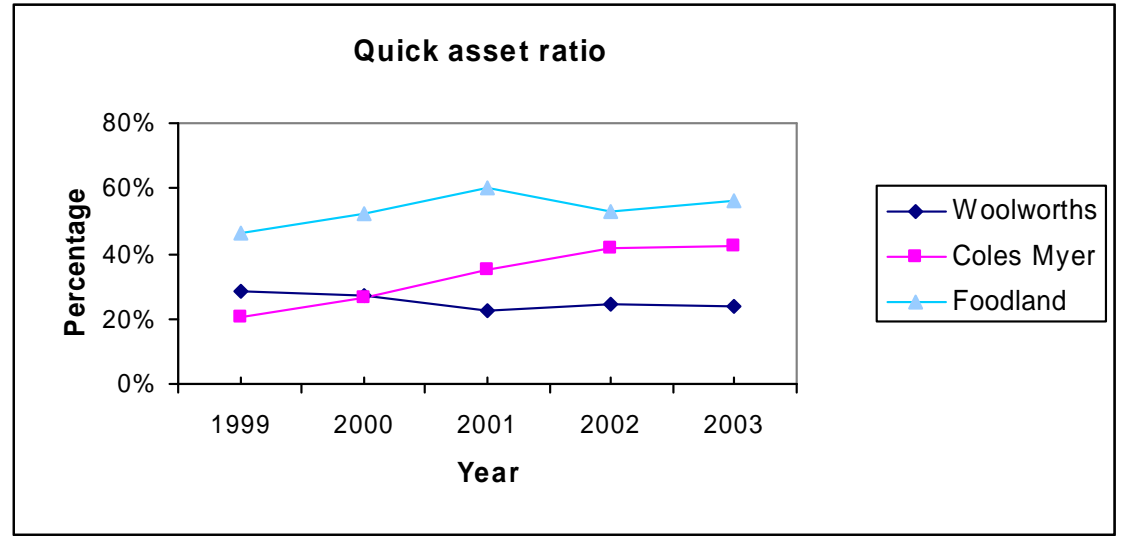

\section{Operating cycle}

\section{Inventory turnover (days)}

Inventory turnover (days) indicates how many days the company holds inventories before selling out. Woolworths' inventory turnover ratio had improved over the past 5 years from 45.87 days in 1999 to 34.1 days in 2003. Comparing to its competitors, Woolworths' inventory turnover is faster than CML (52.52 days) and FOA (34.24 days) in 2003. 


\section{Graph 4: Inventory Turnover (in days)}

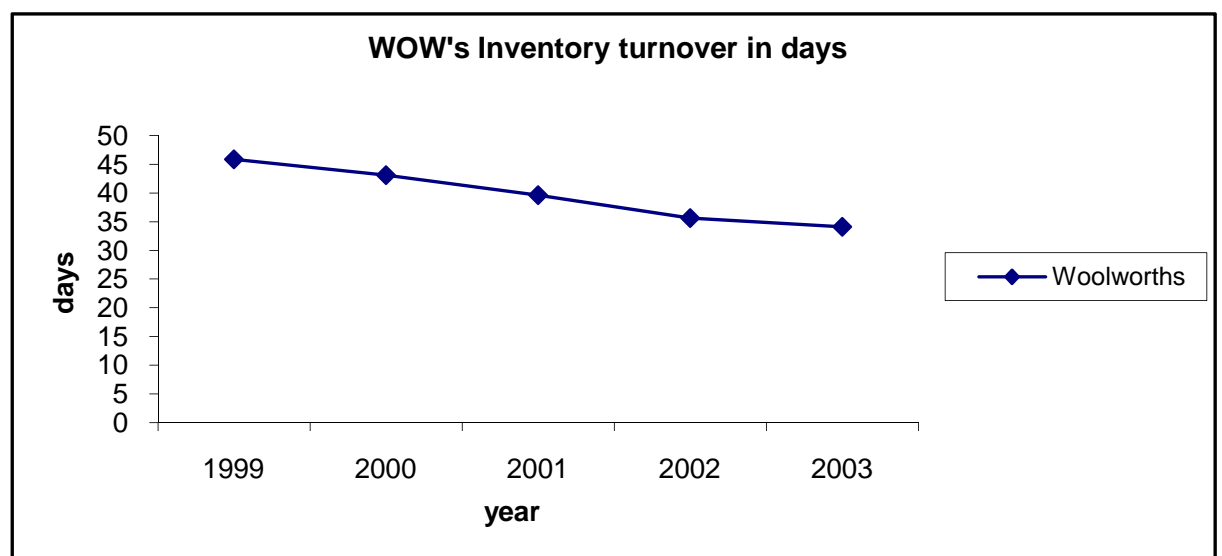

\section{Debtors' turnover (days)}

Debtors' turnover (days) indicates how long the company can collect receivables from its debtors. Woolworths' debtors' turnover rate had been stable over the past 5 years. Comparing to its competitors, Woolworths can collect its receivables (3.6 day) faster than CML (4.68 days) and FOA (14.35 days) in 2003.

The operating cycle is total of inventory turnover in days and debtors' turnover in days. The shorter the operating cycle means the better the company's performance. Thus, Woolworths' operating cycle has been improving from 49.51 days to 37.7 days.

\section{Long term liquidity}

\section{Proprietary ratio based on assets}

It is a measure of how many percent of total assets is contributed by shareholders' equity. Woolworths's ratio has remained constant around 31\% that means for each dollar of invested asset, it is financed by 31 cents of shareholders' funds and 69 cents of debt and outside equity (including income notes). This ratio is lower than Woolworths' competitors (36.7\% in CML and $37.5 \%$ in FOA). 


\section{Graph 5: Proprietary ratio based on assets}

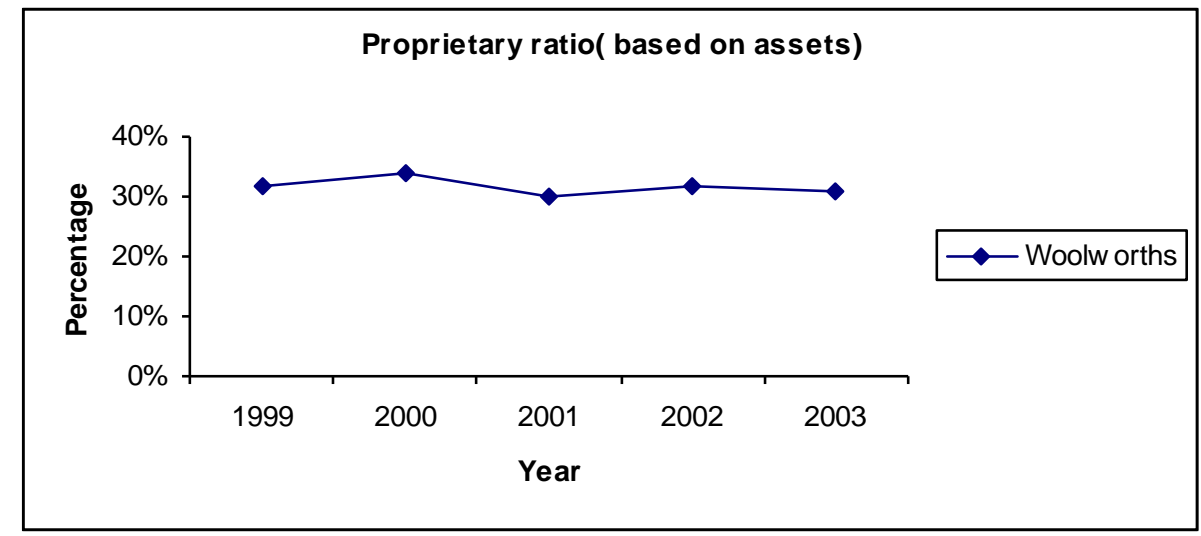

\section{Proprietary ratio based on liabilities}

This ratio measures the level of shareholders' equity in proportion of company's debts. In average, Woolworths has used too much debt. The firm only finance from equity as less than half of the financed debts (equity finance only as $44 \%$ of debt). This ratio has been improved a little in the year 2000 (51.19\%) but after that, it has been decreased again. Even though Woolworth's total equity has been increased by $\$ 338.6 \mathrm{~m}$, its liabilities have also gone up by $\$ 846 \mathrm{~m}$. In comparing with its giant competitor, Coles Myer's ratio has improved from $55.1 \%$ in 1999 to $67 \%$ in 2003.

\section{Graph 6: Proprietary ratio based on liabilities}

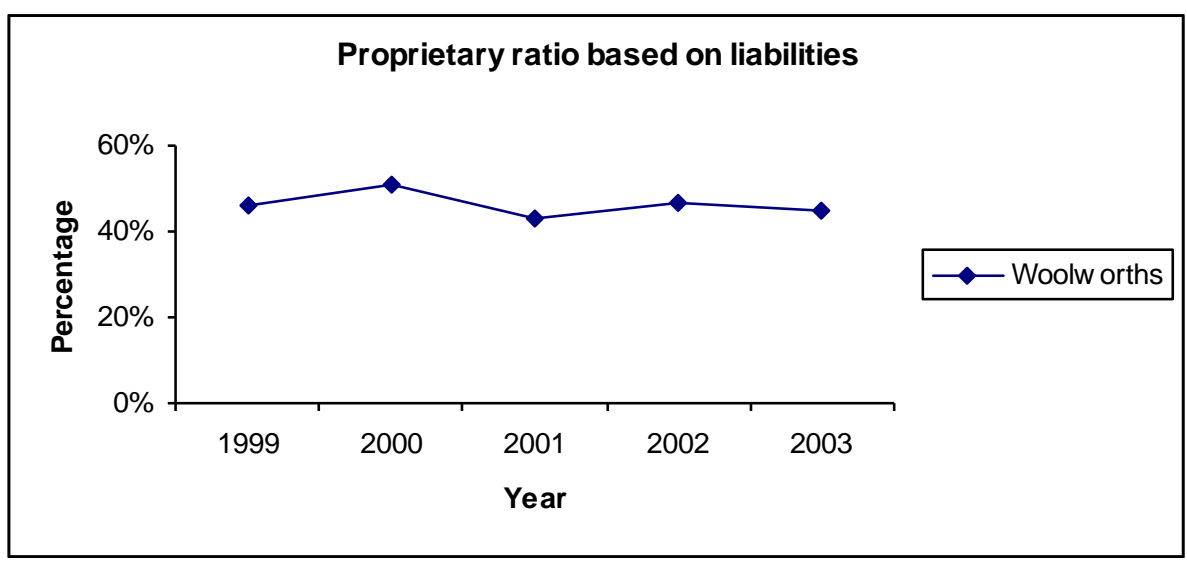




\section{Gearing ratio}

It indicates the proportion of liabilities that contributes to company's total asset. High level of gearing ratio means a high level of borrowing which will affect on the company's stability especially in time of economic crisis. In the case of Woolworths, its ratio is stable around 68 percent over 5 year's period from 1999 to 2003. It exhibits the firm has borrowed heavily. It may be due to the financial advantages by using debts but it also involves a high level of risk. However, in comparing to its competitors, the ratio is just a little higher. Therefore, the ratio is comparable in this industry.

\section{Graph 7: Gearing ratio}

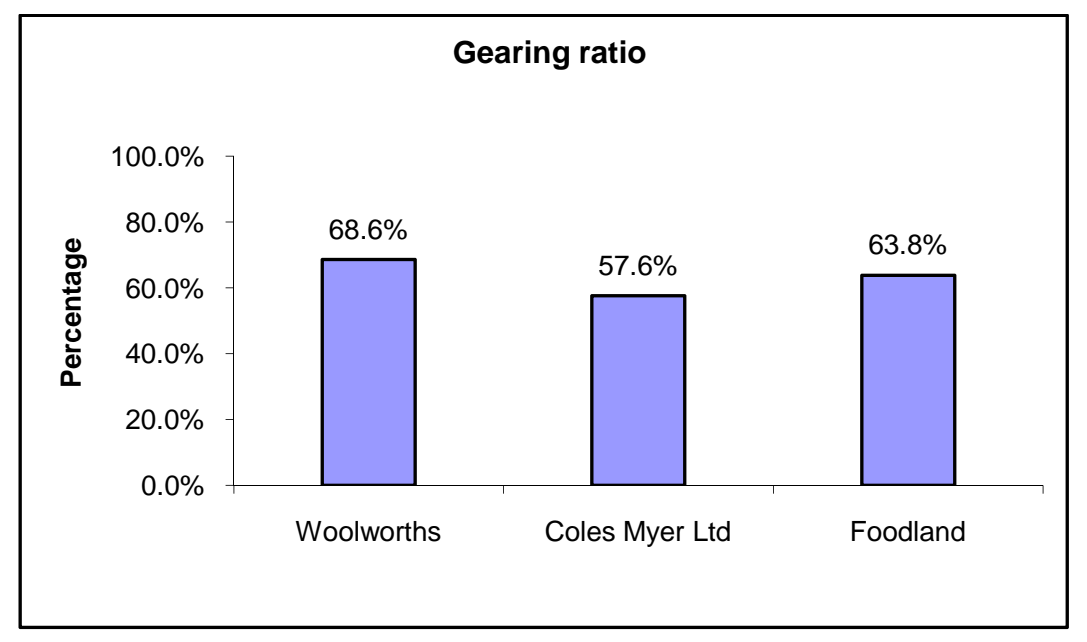

\section{Interest coverage ratio}

Interest coverage ratio shows how company's earnings before interest and tax can cover its interest expenses. Woolworths' interest coverage ratio has increased over the 5 years. As compared to its competitors (8.1 for CML and 3.84 for FOA), Woolworths' interest coverage ratio (11.7) was much higher. 


\section{Graph 8: Interest Coverage Ratio}

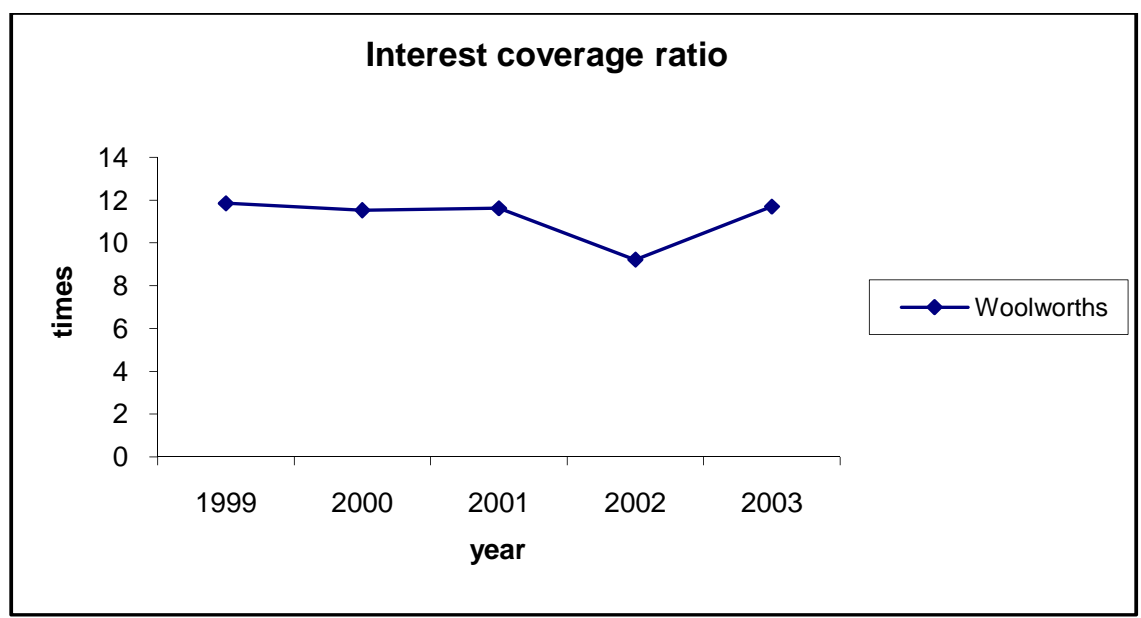

Even though Woolworths' interest coverage ratio is high to cover its interest payment and the principal, the company should decrease the amount of external borrowing to reduce shareholders' risk. When the economy downturn happens, the company may face difficulties to repay its long-term debt.

\section{Ways of Improving Financial Stability}

Based on financial stability analysis, it is suggested that Woolworths should:

- Sell some fixed assets and lease back to improve its short term liquidity

- Shorten operating cycle by optimizing inventory holdings, which can be achieved by maintaining good relationship with suppliers and an effective inventory system such as predetermined reorder points, economic order quantities.

- Improve rate of debt collection which can reduce the operating cycle. For instance, giving more discount to collect debts faster.

- Decrease level of debts by issuing more shares to reduce company's financial risks

- Evaluate company's assets and eliminate non performing assets

\section{Statement of Cash Flow Analysis}

\section{Cash flows from operating activities}

Over the past 5 years, Woolworths' operating cash flows has been increasing except in year 2001. The company has enough cash to pay dividends to its shareholders. In 2002, 
the company generated $\$ 1,174.5$ million of operating cash which is more than enough to cover \$251.5 million paid in dividends. Similarly, in 2003, the company generated $\$ 1,250.6$ million of operating cash which can cover $\$ 307.3$ million paid in dividends.

Further, most of Woolworths' sales are for cash which based on the facts that

- The revenues from operating activities in 2003 were $\$ 26,321.4 \mathrm{~m}$ and the collection from customers was $\$ 27,963.8 \mathrm{~m}$;

- The total for current receivables was only $\$ 242.4 \mathrm{~m}$

Whilst, the reconciliation of net cash provided by operating activities to operating profit after tax showed that receivables decreased by $\$ 16.2 \mathrm{~m}$.

The cash payment to suppliers also increased by $\$ 2,044.5 \mathrm{~m}$ but this was less than the increase in receipts from customers $(\$ 2,259.1 \mathrm{~m})$. However, net cash provided by operating activities has already covered interest and other borrowing costs.

\section{Cash flows from investing activities}

From this section, it indicated that the company purchased other businesses for $\$ 307.9$ million in 2002 and $\$ 41.5$ million in 2003. Moreover, the company has also invested \$596.7 million and \$593.4 million in property, plant, and equipment in 2002 and 2003 respectively. Besides that, the company also sold its property, plant and equipment (\$203.8m in 2002 and \$114.5m in 2003).

\section{Cash flows from financing activities}

From this section, it indicated that Woolworths has used a combination of $96 \%$ of debt $(\$ 1,369.4 \mathrm{~m})$ and $4 \%$ of equity $(\$ 56.7 \mathrm{~m})$ in 2002 . In 2003 , the company increased the use of debt to $98 \%(\$ 4,858.9 \mathrm{~m})$ and decreased the use of equity to $2 \%(\$ 75.6 \mathrm{~m})$. It means that the company has used too much debt to finance its assets. This is not appropriate combination of debt and equity, because the company may be exposed to risks if the interest rates increase. However, the company retired $\$ 4,744.3 \mathrm{~m}$ of debt in 2003 . This strategy may reduce the risks of failure to meet its financial commitments and hence, it will also reduce the risks of bankruptcy. Besides that, over the last four years, the company has bought back total $\$ 1,415.3 \mathrm{~m}$ of its shares. 


\section{Free cash flows}

Woolworths' free cash flows increased substantially from $\$ 390.9 \mathrm{~m}$ in 2002 to $\$ 665.3 \mathrm{~m}$ in 2003. The significant growth was due to strong cash flows from operating activities, driven by a reduction in working capital and strong profit growth.

\section{Common-Size Analysis}

The purpose of using common size statements is to standardize financial statement components by expressing them as a proportion of a relevant base, because firms with different size are difficult to compare (White, Sondhi, and Fried, 2003).

According to the common-size balance sheet in 2003, Woolworths' plant and equipment contribute the largest composition (39.90\%) of total assets. Generally, companies within food and drug retailing industry hold large proportion of plants and equipment comparing with other assets. For example, CML has $39.63 \%$ and FOA $(27.36 \%)$. Meanwhile, inventory takes the second large composition of Woolworths' assets (31.31\%) even though it was still below CML (33.65\%). The company also held a small composition of cash on hands $(4.88 \%)$ of its total assets.

Further, Woolworths reported high proportion of accounts payable (44.55\%) which was higher than its competitors (CML 29.37\% and FOA 18.44\%). The composition of shareholders equity was $30.97 \%$ that was lower than CML $(44.80 \%)$ and FOA $(37.47 \%)$. Whilst, it is noticeable that Woolworths only uses small percentage of long-term debt $(8.43 \%)$ to finance the activities.

Turning to common-size income statement in 2003, we also identify that Woolworths' operating expenses absorbed most of its total revenue (95.01\%), just below Coles-Myer (95.51\%). In fact, it is noticeable that most of companies in the same food retailing industry have high composition of operating expenses. Woolworths has the higher earning before interest and tax (3.51\%) than CML (2.67\%) and FOA $(2.95 \%)$. Similarly, net profit after tax of Woolworths is also higher $(2.41 \%)$ than its competitors, CML $(1.55 \%)$ and FOA (1.55\%). 


\section{Key Market Indicators}

Woolworths' earnings per share have been increasing over the past 5 years from 22.42 cents in 1999 to 58.1 cents in 2003 as well as its price earnings ratio increased from 22.3 times in 1999 to 27 times in 2001 before it decreased to 26.17 times in 2002 and 21.83 times in 2003. It was because significant increase in earnings per share about $25 \%$ from 2001 to 2002 was not followed by equal percentage increase in market share price (only $21 \%$ ). From 2002 to 2003, Woolworths' price earnings ratio decreased substantially due to decrease in its market share price.

The company dividends per share have been increasing from 18.1 cents in 1999 to 38.8 cents in 2003. However, its dividend payout ratio has been decreasing because the company wants to retain the cash for investment in property, plant, and equipment, acquisition of other businesses, and shares buy back. On 14 April 2003, the company has bought back 46.7 million shares at $\$ 11.40$ per share. The total costs of the buy back were \$534.1 million.

\section{CONCLUSION}

In conclusion, in term of financial performance, Woolworths has been doing very well. It can be proved that Woolworths had become the most profitable Australian retailer during 2001. It is believed that Woolworths' performance will improve in the future as long as the company maintains its strategies of cost savings generated by Project Fresh complemented by improved distribution function, stock management and consumer spending.

In short term financial stability, the company's current assets cannot cover its current liabilities (according to current ratio and quick ratio), however, the operating cycle shows that the company's ability to sell out its inventories and collect its account receivables quickly. Therefore, the company may be able to pay up its current liabilities. Regarding long term financial stability, Woolworths depends heavily on debts but the company's earnings before interest and taxes (EBIT) can still cover its interest expense based on its interest coverage ratio (11.7). However, it is very risky to have too much debt because there might be financial stability problems, especially in economic downturn situation. For example, if there is a decline in sales, the company may not be 
able to pay back its debts. Nevertheless, Woolworths has hedged against adverse movement of interest rate by using derivatives products such as forwards, futures, options, and swaps to reduce interest rate risks. Therefore, it is predicted that in the future, the company will still remain in the business.

\section{References:}

Aspect Dat Analysis (http://www.aspectfinancial.com.au/af/company/corpdetails accessed on 26/05/04)

Annual report collection

http:/ / www.connect4.com.au.ezproxy.lib.monash.edu.au/products/ar/index.html accessed on $28 / 05 / 04)$

Bazley, M., Phil Hancock, Aidan Berry, and Robin Jarvis. 2004. Contemporary Accounting. Fifth Edition. Thomson Learning. Australia

Woolworths annual report. 2003. (www.woolworthslimited.com.au accessed on $15 / 5 / 2004)$

White, G. I., Sondhi, A. C and Fried, D. (2003), The Analysis and Use of Financial Statements, Third Edition, John Wiley and Sons Inc., United State of America, p. 114 